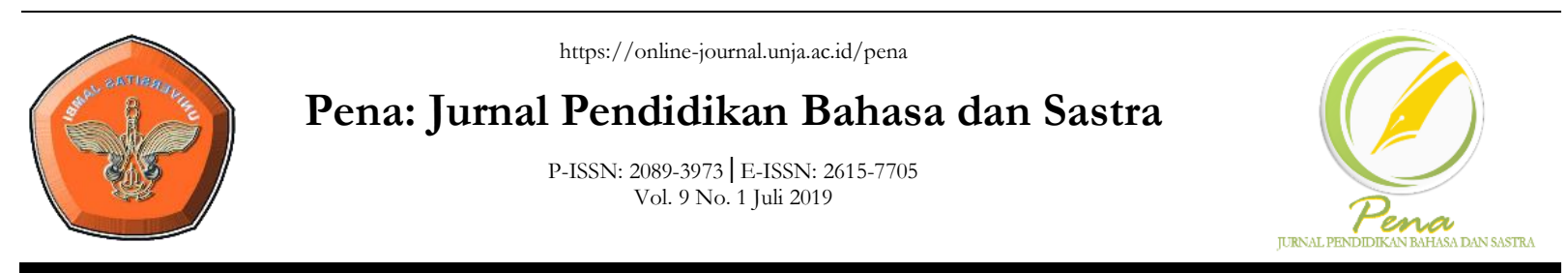

\title{
Bentuk-bentuk Kebahasaan Melayu Pattani dalam Praktik Pidato BIPA dan Implementasinya sebagai Bahan Ajar
}

\author{
Rani Setiawaty, Atiqa Sabardila, Agus Budi Wahyudi \\ Pendidikan Bahasa Indonesia Universitas Muhammadiyah Surakarta \\ a310140096@student.ums.ac.id, as193@ums.sc.id, abw186@ums.ac.id
}

\begin{abstract}
Abstrak
Tujuan penelitian ini untuk (a) mendeskripsikan bentuk-bentuk kebahasaan Melayu Pattani dalam praktik pidato bahasa Indonesia bagi mahasiswa penutur asing; (b) mendeskripsikan pengaruh munculnya bentuk kebahasaan Melayu Pattani dalam praktik pidato bahasa Indonesia bagi mahasiswa penutur asing; (c) mendeskripsikan pemanfaatan temuan sebagai penambah bahan ajar. Data dalam penelitian ini berupa kata, frasa, klausa, kalimat, dan wacana yang mengandung kebahasaan Melayu Pattani dalam pidato mahasiswa penutur bahasa asing. Sumber data penelitian ini ialah teks pidato mahasiswa yang berasal dari Thailand yang menuntut ilmu di program studi Magister Pendidikan Bahasa Indonesia, Universitas Muhammadiyah Surakarta. Teknik pengumpulan data menggunakan teknik simak dan catat. Teknik analisis data meggunakan metode padan dan agih. Metode padan yang digunakan dalam penelitian ini berupa teknik dasar yaitu teknik Pilah Unsur Penentu (PUP). Metode agih berupa berupa teknik perluasan dan baca markah. Hasil penelitian disimpulkan pertama, terdapat bentuk-bentuk kebahasaan Melayu Pattani dalam praktik pidato bahasa Indonesia mahasiswa penutur bahasa asing mencakup bidang fonologi, morfologi, sintaksis, dan sosiolinguistik. Kedua, pengaruh munculnya bentuk kebahasaan Melayu Pattani terdiri atas faktor internal dan eksternal. Faktor internal meliputi bentuk kesalahan berbahasa itu sendiri, sedangkan faktor eksternal meliputi pengaruh latar belakang pendidikan bahasa. Bahasa Thai sebagai bahasa ibu, bahasa melayu sebagai bahasa kedua, dan bahasa Indonesia sebagai bahasa ketiga. Ketiga, hasil temuan dapat dimanfaatkan sebagai penambah bahan ajar bahasa Indonesia kelas XI kompetensi dasar 3.16 dan 4.16.
\end{abstract}

Kata Kunci: Bentuk kebahasaan, pattani, penutur asing

\begin{abstract}
The purpose of this study is to (a) describe Pattani's Malay language forms in the practice of Indonesian speech for foreign speaking students; (b) describe the influence of the emergence of Pattani's Malay language form in the practice of Indonesian speech for foreign speaking students; (c) describe the use of findings as enhancers to teaching materials. The data in this study are words, phrases, clauses, sentences, and discourses that contain Pattani Malay language in the speech of foreign language speakers. The data source of this research is the speech of students from Thailand who are studying in the Indonesian Education Masters program, Mubammadiyah University Surakarta. The data collection technique uses the technique to see and note. The data analysis technique uses the equivalent and fixed method. The equivalent method used in this study is a basic technique, namely the Determination of Determination Element (PUP) technique. The method is in the form of extension techniques and reading markers. The results of the study concluded first, there are Pattani Malay language forms in the practice of Indonesian speech foreign language speakers students cover the fields of phonology, morphology, syntax, and sociolinguistics. Second, the influence of the emergence of Pattani's Malay language form consisted of internal and external factors. Internal factors include the form of language errors themselves, while external factors include the influence of language education background. Thai as a mother tongue, Malay as a second language, and Indonesian as a third language. Third, the findings can be used as enhancers to Indonesian language teaching materials for class XI basic competencies 3.16 and 4.16.
\end{abstract}

Keywords: Linguistic forms, Pattani, foreign speakers

Diterima: Februari 2019. Disetujui: Mei 2019. Dipublikasikan: Juli 2019.

Creative Commons Attribution-NonCommercial-ShareAlike 4.0 International License

DOI: https://doi.org/10.22437/pena.v9i1.6865 


\section{PENDAHULUAN}

Mahasiswa penutur bahasa asing yang menuntut ilmu di program studi Magister Pendidikan Bahasa Indonesia, Universitas Muhammadiyah Surakarta adalah mereka yang belajar bahasa Indonesia sebagai bahasa asing. Konteks ini dipahami bahwa mahasiswa asing yang berasal dari Thailand dapat dikategorikan belajar bahasa Indonesia sebagai pemerolehan bahasa ketiga. Hal ini karena mahasiswa tersebut sudah memiliki bahasa pertama atau bahasa ibu yang berupa bahasa Thai dan bahasa kedua berupa bahasa Melayu, sebelum mereka belajar bahasa Indonesia.

Penguasaan bahasa Indonesia oleh mahasiswa penutur asing dapat dilihat melalui cara pidato. Pidato merupakan pengungkapan pikiran dalam bentuk kata-kata yang ditujukan kepada orang banyak (KBBI, 2016). Pidato yang dipraktikkan tanpa teks dapat digunakan untuk mengetahui kemampuan berbahasa khususnya dalam berbicara. Dalam melakukan praktik pidato tidak luput dari kesalahan berbahasa. Untuk mengetahui kesalahan berbahasa yang dilakukan oleh mahasiswa asing tersebut dapat diketahui melalui analisis kesalahan berbahasa, baik dari segi sintaksis, fonologi, morfologi, dan sosiolinguistik.

Analisis bentuk kebahasaan adalah salah satu cara untuk menjelaskan penggunaan bahasa yang dipakai penutur secara baik dan benar. Sukmawaty (2017:57) analisis adalah suatu proses yang dilaksanakan terhadap suatu peristiwa yang dikaji dan ditelaah sampai ke unsur-unsur yang mendetail sehingga merujuk pada suatu hasil yang diharapkan. Analisis adalah suatu proses yang dilaksanakan terhadap suatu peristiwa yang dikaji dan ditelaah sampai ke unsur-unsur yang mendetail sehingga merujuk pada suatu hasil yang diharapkan.

Beberapa penelitian bentuk-bentuk kebahasaan bagi mahasiswa penutur bahasa asing seperti Damayanti (2016) menemukan bentuk derivasi bahasa Melayu dialek Sambas. Inderasari (2017) menemukan bentuk kesalahan berbahasa pada mahasiswa Thailand yang meliputi tataran ejaan, fonologi, morfologi, sintaksis, dan semantik. Bueraheng, et al. (2017) menemukan kesalahan bentukan kata berafiks dalam karangan mahasiswa Thailand yang berbahasa ibu bahasa Melayu. Santoso, et al. (2018) menemukan kesalahan berbahasa pada pidato mahasiswa yang berperan menjadi calon kepala daerah Kabupaten Blora. Yahya, dkk. (2018) menemukan kesalahan penulisan kalimat dalam karangan pelajar bahasa Indonesia untuk penutur asing (BIPA).

Beberapa hasil penelitian di atas menunjukkan bahwa dalam situasi resmi penggunaan bahasa Indonesia baik mahasiswa penutur bahasa asing maupun penutur asli masih terdapat banyak kesalahan. Anjarsari (2013) menemukan bentuk kebahasaan berupa kesalahan pemakaian bahasa Indonesia dalam karangan mahasiswa asing penutur bahasa asing di Universitas Sebelas Maret. Hasil temuannya disimpulkan bahwa tingkat kesalahan berbahasa dalam karangan mahasiswa penutur bahasa asing meliputi (a) kesalahan berbahasa dalam bidang ejaan sebanyak 53,2\%, (b) 
kesalahan berbahasa dalam bidang morfologi sebanyak 20,4\% (c) kesalahan berbahasa dalam bidang semantik sebanyak $5.3 \%$, (d) kesalahan berbahasa dalam bidang sintaksis sebanyak 21,1\%.

Berdasarkan penelitian sebelumnya di atas, disimpulkan bahwa penelitian kebahasaan dengan subjek mahasiswa penutur bahasa asing belum menyentuh ragam lisan dan hanya sebatas ragam tulis yaitu berupa karangan. Oleh karena itu, peneliti tertarik untuk melakukan penelitian kebahasaan dalam bentuk ragam lisan yang berupa pidato mahasiswa penutur bahasa asing yang telah mempelajari bahasa Melayu sebagai bahasa keduanya. Adapun, judul yang peneliti usulkan yang itu "Bentuk-Bentuk Kebahasaan Melayu Pattani dalam Praktik Pidato Bahasa Indonesia Bagi Mahasiswa Penutur Asing”. Tujuan dari artikel ini, yaitu mendeskripsikan pertama, bentuk-bentuk kebahasaan Melayu Pattani dalam praktik berpidato bagi mahasiswa penutur bahasa asing. Kedua, pengaruh munculnya bahasa Melayu Pattani dalam praktik berpidato bagi mahasiswa penutur bahasa asing.

\section{METODE}

Penelitian ini termasuk jenis penelitian kualitatif. Data dalam penelitian ini berupa kata, frasa, klausa, kalimat, dan wacana yang mengandung kebahasaan Melayu Pattani dalam pidato bahasa Indonesia oleh mahasiswa penutur bahasa asing. Sumber data penelitian ini adalah teks pidato mahasiswa penutur asing yang memerankan diri sebagai ustazah dalam mata kuliah keterampilan berbahasa pada program studi Magister Pendidikan Bahasa Indonesia, Universitas Muhammadiyah Surakarta

Teknik analisis data digunakan untuk menggali permasalahan yang akan dikaji. Teknik analisis data yang digunakan berupa teknik-teknik dalam metode padan (Sudaryanto, 2015:25). Metode padan yang digunakan padan fonetis artikulatoris, dan padan referensial. Selain itu, digunakan metode agih untuk menemukan elemen pengisi kalimat yang mengandung kesalahan berbahasa.

Metode padan yang digunakan dalam penelitian ini berupa teknik dasar yaitu teknik Pilah Unsur Penentu (PUP). Hal yang dipakai analisis dalam teknik PUP ini ialah padan referensial. Adapun teknik yang digunakan dalam metode agih berupa berupa teknik perluasan. Teknik ini dilakukan dengan memperluas satuan lingual. Selain itu, digunakan teknik analisis yang lain berupa teknik baca markah. Teknik baca markah diterapkan dengan melihat langsung pemarkah yang terdapat dalam data. Uji keabsahan data dalam penelitian ini menggunakan trianggulasi teori. Trianggulasi teori dilakukan untuk mengecek keabsahan data dengan menggunakan teori-teori yang dirujuk dari berbagai literatur. 


\section{HASIL DAN PEMBAHASAN}

\section{A. Bentuk-bentuk Kebahasaan Melayu Pattani dalam Praktik Pidato Bahasa Indonesia Bagi Mahasiswa Penutur Asing}

\section{Bidang Fonologi}

Fonologi merupakan ilmu bahasa yang mengidentifikasi satuan-satuan dasar bahasa sebagai bunyi (Verhaar, 2012:67). Bentuk kebahasaan dalam bidang fonologi dalam praktik berpidato mahasiswa penutur bahasa asing yang memerankan diri sebagai ustazah terdiri atas bentuk ringkas penghilangan fonem.

\section{a. Bentuk Ringkas Penghilangan Fonem}

(1) Yang mana é Allah itu mengizinkan é kita-kita semua, ibu-ibu, dan bapak-bapak sekalian ini bisa hadi di majlis ustazah ini ya. (FS/S20018012)

(2) bedoakan supaya kita ini panjangkan usianya supaya kita itu bisa hadi di majlis-majlis yang penuh dengan barakah ini, yah. (FS/S20018012)

(3) Saya percaya kepada ibu-ibu dan bapak-bapak ini sema ini penuh dengan pengalaman. (FS/S20018012)

Data (1), (2), dan (3) terdapat bentuk ringkas akibat penghilangan fonem. Pengucapan kata hadi seharusnya hadir yang berarti ada atau datang (KBBI, 2016). Kata hadi terjadi penghilangan fonem konsonan /r/. Pengucapan kata majlis seharusnya diucapkan majelis yang berarti pertemuan orang banyak. Kata majlis penghilangan fonem vokal /e/. Kata berdoakan terjadi penghilangan konsonan /r/ yang seharusnya diucapkan ber-bukan be-. Pengucapan kata sema seharusnya semua. Hal ini karena terjadi perubahan diftong / ua/ menjadi fonem /a/. Selain itu, kata sepeti pada data (7) seharusnya diucapkan seperti. Hal ini karena terjadi penghilangan fonem konsonan $/ \mathrm{r} /$. Beberapa bentuk ringkas akibat penghilangan fonem tersebut terjadi karena pengaruh dari bahasa Melayu Pattani yang sebelumnya dikuasai penutur. Berikut pembenarannya.

(1a)Yang mana é Allah itu mengizinkan é kita-kita semua, ibu-ibu, dan bapak-bapak sekalian ini bisa hadir di majelis ustazah ini ya.

(1b)Allah telah mengizinkan kita, ibu-ibu, dan bapak-bapak bisa hadir di majelis ustazah ini.

(2a)berdoakan supaya kita ini panjangkan usianya supaya kita itu bisa hadir di majelis-majelis yang penuh dengan barakah ini, yah.

(2b)berdoalah supaya kita dipanjangkan usianya sehingga bisa hadir di majelis-majelis yang penuh dengan barakah.

(3a)Saya percaya kepada ibu-ibu dan bapak-bapak ini semua ini penuh dengan pengalaman.

(3b)Saya percaya kepada ibu-ibu dan bapak-bapak ini penuh dengan pengalaman.

Penelitian ini relevan dengan Anjarsari,dkk. (2013) yang menemukan bentuk kesalahan penulisan huruf pada mahasiswa penutur bahasa asing di Universitas Sebelas Maret. Kesalahan tersebut ditemukan sebagian besar karena mahasiswa penutur bahasa asing hanya mengingat pengucapannya yang masih terpengaruh bahasa pertama mereka, bukan penulisan yang benar sesuai kaidah bahasa Indonesia. Misalnya, kata bawa ditulis bawah, ini terjadi karena kata yang 
berakhiran $h$ pada bahasa pertama mereka cenderung tidak diucapkan, sehingga dibaca bawa. Padahal, kata bawa dan bawah memiliki arti yang berbeda.

\section{b. Bentuk Ringkas Perubahan Fonem}

(4) Lihat juduh malam ini yang penuh dengan barakah. Ustazah memilih juduhnya, yaitu "berubah". (FS/S20018012)

(5) Ya, berubah apakeh? apakeh yang kita tahu tentang kata-kata berubah itu? (FS/S20018012)

(6) Apakeh ibu-ibu dan bapak-bapak sudah terpikir apa yang kita sudah buak sebeluk ini? Dan saya akan memberitahukan tentang definisi atau maknanye tentang "berubah" itu. (FS/S20018012)

(7) Di sini é sepeti kita ini melalui langkah yang petama itu yaitu, bayik apah Roh, setelah roh itu dalam perut kandong ibu. (FS/S20018012)

(8) Walopun kita melakukan dosa besar seperti berzina... (FS/S20018012)

Data (4) sampai dengan (8) terdapat bentuk ringkas perubahan fonem. Kata juduh terjadi perubahan fonem konsonan /l/ menjadi /h/. Seharusnya kata judub diucapkan judul. Kata apakeh terjadi perubahan fonem /a/ menjadi /e/. Hal ini sama dengan kata maknanye yang seharusnya diucapkan maknanya.

Kata buak seharusnya diucapkan buat. Kata ini terjadi perubahan fonem konsonan / $/$ / menjadi $/ \mathrm{k} /$. Kata sebeluk seharusnya diucapkan sebelum. Kata sebeluk terjadi perubahan fonem konsonan $/ \mathrm{m} /$ menjadi $/ \mathrm{k} /$. Kata kandong pada seharusnya diucapkan kandung. Hal ini terjadi perubahan fonem vokal / $\mathrm{u}$ / menjadi fonem vokal /o/. Data (8) terdapat perubahan diftong /au/ menjadi fonem /o/ yang terdapat pada kata walopun yang seharusnya diucapkan walaupun. Berikut pembenarannya.

(4a) Lihat judul malam ini yang penuh dengan barakah Ustazah memilih juduhnya, yaitu "berubah".

(4b) Malam yang penuh dengan barakah ini Ustazah memilih judul yaitu "berubah".

(5a) Ya, berubah apakah? apakah yang kita tahu tentang kata-kata berubah itu?

(6a) Apakah Ibu-ibu dan Bapak-bapak sudah terpikir apa yang kita sudah buat sebelum ini? Dan saya akan memberitahukan tentang definisi atau maknanya tentang "berubah" itu.

(6b) Apakah Ibu-ibu dan Bapak-bapak terpikir apa yang kita sudah perbuat sebelum ini? Saya akan memberitahukan definisi atau maknanya kata "berubah".

(7a) Di sini é sepeti kita ini melalui langkah yang petama itu yaitu, bayik apah Roh, setelah roh itu dalam perut kandung Ibu.

(7b) Di sini seperti kita melalui langkah yang petama yaitu roh. Roh berada dalam perut kandung Ibu.

(8a) Walaupun kita melakukan dosa besar seperti berzina...

Selain itu, perubahan fonem juga ditemukan pada data (27) kata kandong dan melahek. Kata melahek seharusnya diucapkan melahir. Perubahan fonem terjadi karena fonem vokal /i/ diucapkan /e/ dan fonem konsonan /r/ diucapkan /k/. Perubahan fonem pada kata tersebut akibat dari penutur yang terpengaruh bahasa kedua atau bahasa Melayu. 


\section{c. Bentuk Penambahan Fonem}

(9) Syurga bagi kaum kafirun, kaum musyrikin... (FS/S20018012)

Data (9) terdapat kesalahan penambahan fonem pada kata syurga. Kesalahan fonem tersebut berupa fonem konsonan /y/ yang seharusnya tidak diucapkan. Dengan demikian, kata syurga diucapkan surga. Selain itu, data (7) terdapat kesalahan penambahan fonem / k/ pada kata bayik yang seharusnya diucapkan bayi.

(9a) Surga bagi kaum kafirun, kaum musyrikin.

\section{Bidang Morfologi}

Morfologi merupakan cabang linguistik yang menyelidiki morfem bahasa dan penggabungan morfem tersebut menjadi satuuan lingual yang dikenal dengan kata polimorfemik (Rohmadi, dkk. 2012:5) Kesalahan berbahasa mahasiswa asing dalam bidang morfologi meliputi kesalahan penggunaan kata depan, konjungsi, afiks, dan enklitik-nya.

\section{a. Bentuk kata depan}

Rohmadi, dkk. (2012:197) mendefinisikan kata depan atau preposisi sebagai kata yang merangkaikan kata yang berbeda jabatannya atau bagian-bagian kalimat dalam suatu kalimat.

(10) Alhamdulillah puji syukur kehadarat Allah SWT. (FS/S20018012)

Penulisan kata hadarat pada data (12) yang benar adalah hadirat. Kata hadirat berarti hadapan (KBBI, 2016). Dengan demikian, penggunaan kata depan ke seharusnya terpisah dari kata yang mengikutinya. Hal ini karena kata hadirat menunjukkan preposisi. Berikut bentuk perbaikannyaa. (10a) Alhamdulillah puji syukur ke hadirat Allah Swt.

\section{b. Bentuk konjungsi}

Rohmadi, dkk. (2012:195) mendefinisikan kata sambung atau conjunction adalah kata yang menghubungkan kata dengan kata yang lain, menghubungkan bagian kalimat dengan kalimat yang lain atau menghubungkan kalimat dengan kalimat uang lain.

(11) Dan saya akan memberitahukan tentang definisi atau maknanyé tentang "berubah" itu. (FS/S20018012)

(12) Walaupun banyak walaupun kita itu dosanya kita pikir Allah akan memaafkan. Tapi sudah ada ayat Quran yang mengatakan setiap dosa Allah akan ampun atau memaafkan melainkan syirik tidak mengakukan atau tidak mengakukan Allah SWT. (FS/S20018012)

Data (11) konjungsi dan yang berada di awal kalimat menjadikan kalimat tidak efektif. Seharusnya konjungsi tersebut dihilangkan. Data (12) terdapat kesalahan penggunaan konjungsi yaitu walaupun, tapi, dan melainkan. Konjungsi walaupun merupakan konjungsi konsesif. Kesalahan ini terjadi karena penggunaan reduplikasi dan penggunaan kalimat yang mengikutinya tidak tepat. 
Konjungsi tapi biasanya digunakan untuk mempertentangkan sesuatu hal dalam kalimat. Data (12) konjungsi tapi tidak sesuai dengan maksud kalimat sehingga mengaburkan makna kalimat. Seharusnya konjungsi yang digunakan adalah konjungsi antar kalimat, seperti hal ini atau hal tersebut.

Penggunaan kata melainkan merupakan konjungsi pertentangan, sedangkan konteks dalam kalimat menyatakan pembatasan. Jadi, konjungsi yang dipakai seharusnya adalah konjungsi pembatasan bukan konjungsi pertentangan. Konjungsi pembatasan misalnya kecuali atau selain. Data (11) dan (12) perbaikannya sebagai berikut.

(11a)Saya akan memberitahukan tentang definisi atau maknanya tentang "berubah" itu.

(11b) Saya akan memberitahukan definisi atau makna kata "berubah" itu.

(12a) Walaupun banyak kita itu dosanya kita pikir Allah akan memaafkan. Hal ini sudah ada ayat Quran yang mengatakan setiap dosa Allah akan ampun atau memaafkan selain syirik tidak mengakukan atau tidak mengakukan Allah SWT.

(12b) Walaupun kita banyak berbuat dosa Allah akan memaafkan. Hal ini sudah ada dalam ayat Quran bahwa setiap dosa Allah akan mengampuni atau memaafkannya selain syirik yang tidak tidak mengakui Allah Swt.

Penelitian ini relevan dengan penelitian Yahya, dkk. (2018) yang berjudul "Studi Kesalahan Penulisan Kalimat dalam Karangan Pelajar Bahasa Indonesia untuk Penutur Asing (BIPA)”. Hasil penelitiannya ditemukan adanya kesalahan penggunaan konjungsi yang tidak tepat. Contohnya kesalahan yang dilakukan oleh mahasiswa BIPA pada kalimat berupa penggunaan konjungsi dan yang tidak tepat untuk mengawali kalimat, konjungsi ganda berupa karena dan sehingga dalam satu kalimat, ketiadaan konjungsi untuk menghubungkan dua kalimat, dan konjungsi yang tidak lazim dalam bahasa Indonesia seperti oleh itu.

\section{c. Bentuk Berafiks}

Rohmadi,dkk (2013:41) afiksasi ialah proses pembubuhan afiks pada suatu bentuk baik berupa bentuk tunggal meupun bentuk kompleks untuk membentuk kata-kata baru. Afiks ialah suatu bentuk linguistik yang keberadaannya hanya untuk melekatkan diri.

(13) pikirlah kita ini akan kembalikan kepada Allah SWT. (FS/S20018012)

(14) "apa yang kamu lakukan?" "saya ini bunuh orang 99 orang". "Allah tidak memaafkan! (FS/S20018012)

(15) Kita sudah janji kepada Allah, kita ke sini untuk apa? (FS/S20018012)

(16) Sedikit waktu ini untuk kita muhasabah. Musahabah diri kita untuk menjadikan yang lebih bahagia. (FS/S20018012)

(17) Bertaqwa kepada Allah mengikut apa yang disuruh oleh Allah dan tinggal apa yang dilarang. (FS/S20018012)

(18) Walaupun kita melakukan dosa besar seperti berzina, atau pun setiap harian kita buat dosa kecil lama-kelamaan akan menjadi dosa besar. (FS/S20018012)

(19) Dan ingat ya. Setiap langkah setiap perbuatan kita itu Allah akan menghitungkan, mengirakan semua. (FS/S20018012) 
Data (13), (14), (15), dan (16) terdapat penghilangan bentuk prefiks. Data (13) terdapat penghilangan prefiks ber-pada kata pikirlah yang seharusnya diucapkan berpikirlah. Selain itu, juga terdapat penghilangan prefiks di- pada kata kembalikan yang seharusnya diucapkan dikembalikan. Data (14) terjadi kesalahan penghilangan prefiks me- pada kata bunuh. Kata bunuh tersebut seharusnya diucapkan membunuh. Data (15) dan (16) terdapat pernghilangan ber-pada kata janji dan mubasabah. Kata janji seharusnya diucapkan berjanji. Adapun, kata mubasabah seharusnya diucapkan bermuhasabah. Data (20) terdapat penghilangan prefiks di- pada kata bawa yang seharusnya diucapkan dibawa.

Data (16) terdapat penambahan bentuk sufiks -kan pada kata menjadikan yang seharusnya diucapkan menjadi. Data (17) terjadi penghilangan bentuk sufiks $-i$ pada kata mengikut yang seharusnya diucapkan mengikuti. Data (18) terjadi penambahan bentuk sufiks -an pada kata harian yang seharusnya diucapkan hari. Adapun data (19) terjadi kesalahan bentuk prefiks meng- pada kata menghitungkan dan mengirakan yang membuat makna kalimat menjadi rancu. Seharusnya kata tersebut diucapkan memperbitungkan dan memperkirakan. Berikut perbaikannya.

(13a) berpikirlah kita ini akan dikembalikan kepada Allah SWT.

(13b) berpikirlah kita akan dikembalikan kepada Allah Swt.

(14a)"Apa yang kamu lakukan?" "Saya ini membunuh orang 99 orang". "Allah tidak memaafkan!"

(15a) Kita sudah berjanji kepada Allah, kita ke sini untuk apa?

(16a) Sedikit waktu ini untuk kita bermuhasabah. Berusahabah diri kita untuk menjadi yang lebih bahagia.

(17a)Bertaqwa kepada Allah mengikuti apa yang disuruh oleh Allah dan meninggal apa yang dilarang.

(17b) Bertaqwalah kepada Allah dengan mengikuti apa yang disuruh dan meninggal apa yang dilarang.

(18a)Walaupun kita melakukan dosa besar seperti berzina, atau pun setiap hari kita berbuat dosa kecil lama kelamaan akan menjadi dosa besar.

(18b)Walaupun kita melakukan dosa besar seperti berzina ataupun setiap hari kita berbuat dosa kecil lama-kelamaan akan menjadi dosa besar.

(19a) Ingat, ya. Setiap langkah setiap perbuatan kita itu Allah akan memperhitungkan, memperkirakan semua.

Penelitian ini relevan dengan hasil penelitiannya Selain itu, Bueraheng (2017) menemukan bentuk berafiks yang kurang tepat ditinjau dari konteksnya. Bentuk tersebut meliputi (1) penghilangan afiks (prefiks, sufiks, dan konfiks), (2) penambahan afiks (prefiks dan sufiks), dan (3) kerancuan penggunaan afiks (prefiks dan konfiks) pada mahasiswa Thailand yang berbahasa Ibu bahasa Melayu.

Ramaniyar (2016) menemukan bentuk kebahasan afiksasi dalam bahasa Melayu (kajian morfologi) meliputi bə-,(ber) yang menyatakan makna suatu perbuatan aktif, serta menyatakan makna kumpulan yang terdiri dari jumlah bentuk dasar sedangkan afiks də-(di-) menyatakan makna yang pasif. Damayanti (2016) juga menemukan bentuk derivasi bahasa Melayu dialek Sambas yang 
berupa afiks pembentuk verba dalam bahasa Melayu. Afiks tersebut melibuti, prefiks be-, prefiks di-, prefiks me, prefiks ti-, sufiks -kan, sufiks -ek, simulfiks $N$-kan, simulfiks $N$-an, konfiks di-kan, konfiks di-ek, konfiks me-ek, konfiks be-kan, dan konfiks si-an.

\section{d. Bentuk enklitik}

Bentuk enklitik merupakan bentuk yang hampir menyerupai afiks namun memiliki makna leksi. Dengan demikian, bentuk-bentuk enklitik masih tergantung pada bentuk dasar lain agar memiliki fungsi (Rohmadi, dkk. 2013:78). Enklitik -nya merupakan morfem setengah bebas yang melekat pada bagian belakang kata seperti sebuah sufiks.

(20) Lalu, sepertinya ibarat dua malaikat bertengkar maunya bawa ke syurga atau neraka. (FS/S20018012)

(21) Ulama itu bilang "Tetapi dengan satu syarat. Kamu harus berpindah dari tempat ini. Karena satu syarat hijrahnya kamu harus pindah dari tempat yang lain mungkin tempat itu tidak sesuai bagi kamu," Ya, sepertinya begitu. Dia itu dalam perjalanan mau berubah waktu itu dia mati, matinya di situ. (FS/S20018012)

(22) Lalu, yang ianya dengan yang baik seperti dia itu sebagai ahli syurga. (FS/S20018012)

Data (20) sampai dengan (22) terdapat kesalahan bentuk enklitik. Kata sepertinya dan mannya pada data (20) merupakan bentuk enklitik - nya yang berlaku sebagai akhiran/sufiks. Pada data tersebut kata sepertinya diikuti kata ibarat bermaksud sama, yaitu memberi contoh analogi. Sedangkan, kata sepertinya pada data (21) merujuk pada benar tidaknya ucapan ulama kepada seorang pemuda yang diceritakan oleh mahasiswa asing penutur bahasa Indonesia. Penutur menggunakan kata sepertinya menunjukkan adanya keraguan terhadap pernyataan yang diungkapkan.

Enklitik -nya pada kata mannya, matinya, ianya, dan bijrabnya merupakan akhiran/ sufiks. Enklitik tersebut jika dihilangkan tidak mengubah suatu makna. Dengan demikian, penggunaan enklitik nya pada data (20) sampai (22) menimbulkan kalimat menjadi tidak efektif.

Bentuk enklitik -nya juga terdapat pada data (4), yaitu pada kata judulnya menunjukkan pemilikan. Namun, bentuk posessiva atau pemilikan tersebut tidak jelas sehingga membuat kalimat menjadi tidak logis. Seharusnya enklitik -nya juga dihilangkan seperti data (4b) Malam yang penuh dengan barakah ini Ustazah memilih judul yaitu "berubah". Berikut pembenaran data (20), (21), dan (22).

(20a) Lalu, seperti dua malaikat bertengkar mau dibawa ke surga atau neraka.

(20b) Lalu, ibarat dua malaikat bertengkar akan dibawa ke surga atau neraka.

(21a) Ulama itu bilang “Tapi dengan satu syarat. Kamu harus pindah dari tempat ini. Karena satu syarat hijrah kamu harus pindah dari tempat yang lain mungkin tempat itu tidak sesuai bagimu," Ya, sepertinya begitu. Dia itu dalam perjalanan mau berubah waktu itu dia mati, mati di situ. 
(21b) Ulama itu berkata "Tetapi dengan satu syarat. Kamu harus berpindah dari tempat ini. Karena satu syarat hijrah kamu harus pindah dari tempat lain yang mungkin tempat itu tidak sesuai bagimu," Ya, sepertinya begitu. Dia dalam perjalanan mau berubah tetapi dia mati.

(22a) Lalu, yang ia dengan yang baik seperti dia itu sebagai ahli syurga.

(22b) Lalu, ia dengan yang baik seperti ahli syurga.

\section{e. Bentuk interjeksi atau kata seru}

Interjeksi atau kata seru merupakan kata yang mengungkapkan seruan perasaan. Bentuk interjeksi dalam praktik pidato mahasiswa penur bahasa asing sebagai berikut.

(23) Apa yang maksud berubah itu yaitu berpindah atau berhijrah itu berpindah di antara suatu tempat ke tempat yang lain, iya!. (FS/S20018012)

(24) Lalu, ulama itu bilang owh... Allah itu Maha pengampun, Maha... Allah akan memaafkan setiap dosa melainkan dosa syirik. (FS/S20018012)

Bentuk interjeksi terdapat pada data (23) dan (24). Interjeksi iya pada data (23) berfungsi sebagai pembenaran pernyataan yang dituturkan. Bentuk interjeksi owh... pada data (24) berfungsi sebagai ungkapan keheranan oleh penutur.

\section{Bidang Sintaksis}

Sintaksis merupakan cabang ilmu bahasa yang membicarakan seluk beluk wacana, kalimat, klausa, dan frase, berbeda dengan morfologi yang membicarakan seluk beluk kata dan morfem (Ramlan dalam Markhamah, 2009:5). Adapun bentuk kebahasaan bidang sintaksis dalam praktik pidato mahasiswa penutur bahasa asing sebagai berikut.

\section{a. Bentuk kesalahan pemilihan kata}

Kesalahan pemilihan dan penyusunan kata dapat membuat kalimat tidak logis. Menurut Markhamah, dkk. (2014:152) kelogisan hubungan antar unsur dalam kalimat salah satunya ditentukan oleh penggunaan kata penghubung dan ketepatan hubungan antara kata satu dengan kata lain.

(25) Langsung kita ini habis semangat dan ambil pisau dibunuhkan pula ustad atau ulama' itu. (FS/S20018012)

Data (25) terjadi kesalahan pemilihan diksi/ kata dalam membentuk kalimat. Kata yang salah tersebut terdapat pada kata habis. Hal tersebut menyebabkan makna kalimat menjadi tidak logis. Seharusnya kata habis diganti bilang. Konjungsi koordinatif dan diganti dengan konjungsi temporal kemudian. Kata ambil diganti mengambil, dan kata pula diganti kepada.

(25a) Langsung kita hilang semangat kemudian mengambil pisau dibunuhkan kepada ustad atau ulama' itu. 
Bentuk kesalahan penggunaan kata juga terdapat pada data (14). Kesalahan tersebut terletak pada kata yang mengatakan, ampuni, melainkan, dan mengakukan membuat kalimat tidak bisa diterima oleh akal sehat. Penggunaan kata yang mengatakan seharusnya diganti konjungsi penjelas berupa konjungsi bahwa. Adapun, pemilihan kata ampuni tidak sejajar dengan kata memaafkan yang dihubungkan oleh konjungsi atau. Dengan demikian, kata yang digunakan seharusnya mengampuni seperti pada data (14b).

Selain itu, terdapat bentuk kesalahan penggunaan kata serapan yang tidak tepat seperti data (1) yaitu yang mana. Kata serapan merupakan serapan dari where dan which (Markhamah, dkk, 2014:150). Dengan demikian, agar tidak mengaburkan makna kata yang mana seharusnya dihilangkan seperti data (1b) Allah telab mengizinkan kita, ibu-ibu, dan bapak-bapak bisa hadir di majelis ustazah ini.

Penelitian ini relevan dengan penelitiannya Budiawan dan Rukayati (2018) yang menemukan kesalahan bahasa dalam praktik berbicara pemelajaran bahasa Indonesia bagi penutur asing (BIPA) di Universitas PGRI Semarang tahun 2018. Kesalahan tersebut berupa kesalahan kalimat yang dapat dibagi menjadi 3 jenis, yaitu (a) kesalahan pilihan kata, (b) kesalahan dalam penggunaan afiks, dan (c) ketidakefektifan kalimat. Ada beberapa faktor yang menyebabkan pemelajar melakukan kesalahan, diantaranya faktor psikologis (gugup/ grogi), penguasaan topik, kurangnya kosa kata, pemilihan kata, pemahaman tata bahasa dan tata kalimat, dan interferensi bahasa ibu (B1).

\section{b. Bentuk mubadzir}

(26) Ya, yang pertama kali itu kita ini panjatkan puji syukur ke hadarat Allah SWT. (FS/S20018012)

Data (26) terdapat bentuk mubadzir yang berupa kata seru $Y$ a, kata perujukan itu, dan ini. Kalimat yang mengandung kata mubadzir ialah kalimat yang berlebih-lebihan sehingga mengakibatkan tidak hemat, sia-sia, dan tidak berguna. Kemubadziran adalah kesalahan berbahasa yang disebabkan oleh penggunaan kata yang tidak diperlukan (Markhamah, 2014:148). Pembenaran data tersebut sebagai berikut.

(26a) Pertama kali kita panjatkan puji syukur ke hadarat Allah Swt.

Selain itu, data (6) dan (11) juga mengandung kata mubadzir tentang yang membuat kalimat menjadi bertele-tele. Pembenaran data (6) seperti pada data (6b) Apakah Ibu-ibu dan Bapak-bapak terpikir apa yang kita sudah perbuat sebelum ini? Saya akan memberitabukan definisi atau maknanya kata "berubah". Data (11) mengandung kata mubadzir berupa yang dan itu. Kedua kata tersebut membuat kalimat menjadi tidak efektif. Hal tersebut jika dihilangkan tidak akan mengubah intisari dari 
gagasan yang disampaikan penutur. Pembenaran data kata tersebut seperti pada data (11b) Saya akan memberitabukan definisi atau makna kata "berubab" itu.

\section{c. Bentuk repetisi atau pengulanagan}

(27) Setelah dalam kandong ibu itu kita melahék menjadi bayi, dan setelah itu syabab atau remaja, setelah itu kita dewasa dan tua, dan setelah itu kita akan kembalikan kepada tempat asal, yaitu kita akan kembali kepada kubur Allah SWT. (FS/S20018012)

(28) Dan walau apa? Ingat! walau apapun yaitu kita buat salah, kita itu buat dosa besar itu. (FS/S20018012)

(29) Langkah yang ada suatu hadis mengatakan langkah atau syabab atau langkah syabab atau langkah remaja itu kita akan ditanyakan atau disoalkan yang paling berat. (FS/S20018012)

Data (27), (28), dan (29) terdapat pengulangan kata atau repetisi sehingga membuat kalimat menjadi tidak efektif. Data (27) terdapat repetisi konjungsi waktu atau temporal berupa setelah itu. Data (28) terdapat repetisi konjungsi konsesif berupa walau. Data (29) terdapat repetisi berupa pengulangan kata langkah. Repetisi tersebut sebaiknya dihindari agar kalimat yang disampaikan menjadi efektif, seperti data (27a), (28a), (29a) atau (29b).

(27a) Setelah dalam kandung ibu kita melahir menjadi bayi kemudian syabab atau remaja, setelah itu dewasa dan tua, kemudian kita akan dikembalikan kepada tempat asal, yaitu kita akan dikembalika kepada kubur Allah Swt.

(28a) Walau apa? Ingat! walaupun kita berbuat salah, kita sudah berbuat dosa besar.

(29a) Langkah yang ada suatu hadis mengatakan kita akan ditanyakan atau disoalkan yang paling berat.

(29b) Suatu hadis mengatakan langkah pertama kita akan ditanyakan atau dipersoalkan yang paling berat.

\section{d. Bentuk Pleonasme}

Contoh data (1) mengandung bentuk pleonasme. Pleonasme dipakai untuk menandai kesalahan berbahasa karena pemakaian kata yang berlebihan yang berupa penggunaan kata bersinonim dan dua pernyataan bentuk jamak (Markhamah, dkk, 2014:149). Pleonasme data (1) berupa kita-kita semua dan bapak-bapak sekalian. Penggunakaan kata-kata tersebut membuat kalimat terkesan berlebihan. Sebaiknya diucapkan seperti (1b) Allab telah mengizinkan kita, ibu-ibu, dan bapakbapak bisa hadir di majelis ustazah ini.

Penelitian ini relevan dengan Yahya, dkk (2018) yang berjudul “Tendensi Kesalahan Sintaksis Bahasa Tulis Pembelajar Bahasa Indonesia Bagi Penutur Asing (BIPA)". Kesamaan dengan penelitian ini terletak pada kesalahan sintaksis yang dilakukan oleh mahasiswa asing yang belajar bahasa Indonesia. Yahya, dkk (2018) menemukan adanya kesalahan sintaksis bahasa Indonesia pembelajar BIPA berupa pengaruh bahasa asing/daerah, penggunaan preposisi yang tidak tepat, kesalahan susunan kata, penggunaan unsur yang berlebihan atau mubazir, penjamakan yang ganda, dan penggunaan resiprokal yang tidak tepat, kalimat yang tidak logis, dan kalimat yang ambigu. 


\section{Bidang Sosiolinguistik}

Menurut Ngalim, dkk. (2015:17) sosiolinguistik merupakan salah satu disiplin ilmu yang membahas penggunaan bahasa dalam masyarakat sosial. Bentuk kebahasaan dalam bidang sosiolinguistik yang terdapat dalam pidato mahasiswa penutur bahasa asing yang memerankan diri pidato ustazah sebagai berikut.

\section{a. Bentuk Interferensi}

Bentuk kebahasaan dalam bidang sosiolinguistik terjadi karena adanya kontak bahasa atau interferensi. Menurut Brown (dalam Mutoharoh, 2018:86) interferensi merupakan transfer negatif yang terjadi ketika performa sebelumnya mengganggu performa pembelajaran sesudahnya, yang mana materi-materi yang dipelajari sebelumnya mencampuri materi-materi berikutnya. Kridalaksana (dalam Sukoyo, 2011: 97) interferensi adalah penyimpangan kaidah-kaidah suatu bahasa yang terjadi pada orang bilingual sebagai akibat penguasaan dua bahasa. Penyebab interferensi yang lain adalah kurangnya penguasaan kaidah kebahasaan secara benar.

Nurhadi (dalam Mutoharoh, 2018:87) menyatakan adanya tiga penyebab utama interferensi yaitu, (1) language transfer, yaitu kesalahan sebagai akibat adanya bahasa ibu (B1); (2) intralingual, yaitu kesalahan yang bukan berupa interferensi, melainkan sebagai akibat dari proses belajar itu sendiri (kekhilafan perkembangan); dan (3) teaching techniques or materials (process hypothesing flaseconcepts) yaitu interferensi akibat kesalahan teknik mengajar atau materi. Penggunaan Interferensi dalam pidato mahasiswa penutur asing asal Thailand berupa alih kode dan campur kode.

\section{1) Bentuk alih kode}

(30) Assalamualaikum was assalamualaikum wassalatu wassala muala asyrafa ambiyai walmusalim wa ala alihi asrofil ajmaiin. Alhamdulillah puji syukur kehadarat Allah SWT. Yang mana é Allah itu mengizinkan é kita-kita semua, ibu-ibu, dan bapak-bapak sekalian ini bisa hadi di majlis ustazah ini ya. (FS/S20018012)

Data (30) terdapat interferensi alih kode dari bahasa Arab ke bahasa Indonesia.

\section{2) Bentuk campur kode}

Campur kode terdapat pada data (27) dan (16) terdapat bentuk interferensi campur kode bahasa Melayu, Arab dan bahasa Indonesia. Bahasa Melayu tersebut terdapat pada kata syabab yang berarti langkah dan campur kode bahasa Arab terdapat pada kata mubasabah yang berati interospeksi.

Hasil penelitian ini relevan dengan yang dilakukan oleh Mutaharoh, dkk (2018) menemukan interferensi pada karangan narasi mahasiswa Thailand semester IV PBSI FKIP Universitas Muhammadiyah Tangerang. Temuannya menunjukkan bahwa banyaknya kata yang terinterferensi 
pada bentuk afiksasi kategori prefiks, sufiks, kombinasi afiks, konfiks, reduplikasi, dan komposisi sedangkan pada afiks kategori infiks tidak terdapat interferensi. Abdurrahman (2013) juga menemukan interferensi morfologis bahasa Melayu berupa aspek afiksasi, reduplikasi, komposisi, dan akronimisasi.

\section{b. Bentuk ragam tidak formal}

(31) Karena waktu remaja kan banyak melakukan kesalahan seperti itu. (FS/S20018012)

(32) Lihat, tapi ada suatu hadis yang saya mau mengingatkan kepada ibu-ibu dan bapak-bapak. Emm.. apa? (FS/S20018012)

(33) Ya. Iya, emm....(FS/S20018012)

Penggunaan kata kan, emm.. Ya. Iya, emm... dan owh pada data (31), (32), dan (33) menunjukkan kata tidak baku atau nonformal dalam situasi formal. Selain itu, data (21) juga terdapat kesalahan pemilihan kata bilang. Seharusnya kata tersebut diucapkan dengan berkata. Penggunaan interjeksi dan kata bilang dalam pidato mahasiswa penutur bahasa asing yang memerankan ustazah menunjukkan ragam bahasa yang digunakan tidak formal.

Penggunaan kata beragam tidak formal menunjukkan bahwa terjadi kesenyapan diam saat mahasiswa asing berpidato memerankan diri sebagai ustazah. Senyapan diam adalah keadaan ketika penutur berhenti sejenak dan diam saja, penutur melanjutkan tuturannya ketika sudah menemukan kata-kata yang tepat, sedangkan senyapan terisi adalah keadaan ketika penutur berhenti sejenak untuk menemukan kata yang tepat dengan mengisinya dengan kata-kata seperti “anu", "apa itu”, “eh”, “uh” (Dardjowidjojo, 2003:144).

Hasil penelitian ini sesuai dengan penelitian Budiawan dan Rukayati (2018) yang menemukan kesenyapan berupa emm dan aaa dalam praktik berbicara pemelajaran bahasa Indonesia bagi penutur asing (BIPA) di Universitas PGRI Semarang tahun 2018. Dardjowidjojo (2003:144) mengatakan bahwa kebiasaan berbicara sambil berpikir berpotensi menyebabkan senyapan, semakin sulit topik yang dipikirkan, semakin besar potensi senyapan yang dihasilkan. Oleh karena itu, penguasaan topik merupakan faktor yang sangat penting dalam berbicara. Ketika seseorang tidak menguasai topik maka ia tidak tahu hal yang ingin disampaikan. Hal tersebut tentu sangat mengganggu keefektifan dalam berbicara.

\section{B. Pengaruh Munculnya Bentuk Kebahasaan Melayu Pattani dalam Praktik Pidato Bahasa Indonesia Bagi Mahasiswa Penutur Asing.}

\section{Faktor Internal}

Mahasiswa penutur asing yang berasal dari Thailand belum memahami tataran fonologi, khususnya pengucapan fonem bahasa Indonesia masih terpengaruh dengan bahasa Melayu. 
Tataran morfologi bahasa Indonesia, khususnya pada penggunaan afiksasi. Pemahaman dalam memilih afiksasi tersebut masih sering mengalami kekeliruan seperti pada prefiks dan sufiks. Tataran sintaksis belum memahami struktur kalimat yang baik. Hal ini karena pengetahuan terhadap kosa kata bahasa Indonesia belum maksimal sehingga mengakibatkan mahasiswa tersebut sering mecampur-adukkan bahasa Indonesia dengan bahasa Melayu. Selain itu, dalam bertutur mahasiswa tersebut juga banyak melakukan repetisi, penggunaan kata mubazir dan pleonasme sehingga penyampaian maksud pidato menjadi tidak efektif.

\section{Faktor Eksternal}

Faktor eksternal yang mempengaruhi adanya bentuk kebahasaan Melayu Pattani dalam pidato bahasa Indonesia bagi mahasiswa penutur asing yaitu adanya pengaruh latar belakang pendidikan bahasa. Bahasa yang dikuasai oleh mahasiswa Thailand program studi Magister Pendidikan Bahasa Indonesia, Universitas Muhammadiyah Surakarta, yakni bahasa Thailand sebagai bahasa pertama (B1) dan bahasa Melayu sebagai bahasa kedua (B2). Bahasa pertamanya adalah bahasa Thai yang diperoleh secara alami melalui kebiasaannya bertutur dengan orang Thailand. Sedangkan bahasa keduanya diperoleh karena kedekatan rumpun Melayu, sehingga mereka menguasai bahasa Melayu. Sedangkan, untuk bahasa ketiga yaitu bahasa Indonesia (B3).

\section{Implementasi Sebagai Penambah Bahan Ajar}

Hasil penelitian ini dapat dimanfaatkan sebagai bahan ajar bahasa Indonesia di SMA/MA Kelas XI dengan Kompetensi Dasar 3.6 Menganalisis isi, struktur, dan kebahasaan dalam ceramah dan Kompetensi Dasar 4.6 Mengkonstruksi ceramah tentang permasalahan aktual dengan memerhatikan aspek kebahasaan dan menggunakan struktur yang tepat (Permendikbud Nomor 37 Tahun 2018 Tentang KI dan KD). Kompetensi dasar tersebut sangat relevan dengan hasil temuan kebahasaan dalam teks pidato yang diperan oleh mahasiswa penutur asing. Dengan demikian, hasil temuan ini dapat dijadikan contoh bahan ajar sehingga peserta didik dapat meminimalisasi kesalahan berbahasa baik pengucapan bunyi, pleonasme, kemubaziran, kata tidak baku, repetisi, penggunaan verba, penggunaan konjungsi. Berikut contoh pemanfaatan hasil temuan sebagai bahan ajar.

Bapak-bapak dan Ibu-ibu yang saya hormati. Ingat ya, setiap langkah atau perbuatan kita Allah akan memperbitungkannya. Terdapat suatu hadis yang saya ingin sampaikan kepada ibu-ibu dan bapak-bapak. Suatu badis mengatakan babwa ketika remaja kita akan dipertanyakan atau dipersoalkan suatu perbuatan yang paling berat. Hal ini karena apa? Karena waktu remaja kita banyak melakukan kesalahan. Kelak kita ingin dikembalikan supaya bisa menuaikan ibadah tetapi itu tidak memungkinkan. Oleh karena itu, untuk menghindari penyesalkan kelak kita harus beribadah kepada Allah SWT. Bertaqwa kepada Allah mengikuti apa yang disurub oleh Allah dan tinggal apa yang dilarang. 
Kegiatan Siswa

Berdasarkan kutipan teks ceramah di atas! Jawablah pertanyaan-pertanyaan berikut!

1. Tentukan bagian struktur kutipan teks ceramah di atas!

2. Identifikasilah kaidah-kaidah kebahasaan kutipan teks ceramah di atas!

3. Kembangkan kutipan teks di atas menjadi sebuah konstruksi teks ceramah yang lengkap!

\section{SIMPULAN}

Berdasarkan hasil pembahasan dapat disimpulkan pertama, terdapat bentuk-bentuk kebahasaan Melayu Pattani dalam praktik pidato bahasa Indonesia mahasiswa penutur bahasa asing mencakup bidang fonologi, morfologi, sintaksis, dan sosiolinguistik. Bentuk kebahasaan Melayu Pattani bidang fonologi meliputi bentuk ringkas penghilangan fonem, bentuk ringkas perubahan fonem, dan bentuk penambahan fonem. Bidang morfologi meliputi bentuk kata depan, bentuk konjungsi, bentuk berafiks, bentuk enklitik, dan bentuk interjeksi. Bidang sintaksis meliputi bentuk pemilihan kata, bentuk mubadzir, bentuk repetisi, dan bentuk pleonasme. Bidang sosiolinguistik meliputi meliputi bentuk interferensi dan ragam tidak formal. Kedua, pengaruh munculnya bentuk kebahasaan Melayu Pattani terdiri atas faktor internal dan eksternal. Faktor internal meliputi bentuk kesalahan berbahasa itu sendiri, sedangkan faktor eksternal meliputi pengaruh latar belakang pendidikan bahasa. Bahasa Thai sebagai bahasa ibu, bahasa melayu sebagai bahasa kedua, dan bahasa Indonesia sebagai bahasa ketiga. Ketiga, hasil temuan dapat dimanfaatkan sebagai penambah bahan ajar bahasa Indonesia kelas XI kompetensi dasar 3.16 dan 4.16.

\section{DAFTAR RUJUKAN}

Abdurrahman, A., Ngusman, N., \& Nursaid, N. (2013). Interferensi Morfologis Bahasa Melayu Betawi terhadap Bahasa Minangkabau Remaja Kota Padang. Pendidikan Bahasa dan Sastra Indonesia, 1(2), 399-405.

Anjarsari, N., Suwandi, S., \& Mulyono, S. (2013). Analisis kesalahan pemakaian bahasa Indonesia dalam karangan mahasiswa penutur bahasa asing di Universitas Sebelas Maret. BASASTRA, 1(2), 250-262.

Badan Pembinaan dan Pengembangan Bahasa Indonesia. 2016. Kamus Besar Bahasa Indonesia Edisi $V$. Jakarta: Kemendikbud RI.

Budiawan, R. Y. S., \& Rukayati, R. (2018). Kesalahan Bahasa dalam Praktik Berbicara Pembelajaran Bahasa Indonesia bagi Penutur Asing (Bipa) di Universitas PGRI Semarang Tahun 2018. KREDO: Jurnal Ilmiah Bahasa dan Sastra, 2(1), 88-97.

DOI: https://doi.org/10.24176/kredo.v2i1.2428

Bueraheng, R., Suyitno, I., \& Susanto, G. (2017). Kesalahan Bentukan Kata Berafiks dalam Karangan Mahasiswa Thailand yang Berbahasa Ibu Bahasa Melayu. Jurnal Pendidikan: Teori, Penelitian, dan Pengembangan, 2(6), 756-762.

Damayanti, W. (2016). "Bentuk Derivasi Bahasa Melayu Dialek Sambas. Jurnal Kandai, 12(2): 255268. 
Dardjowijojo, Soenjono. 2003. Psikolinguistik: Pemahaman Bahasa Manusia. Jakarta: yayasan Obor Indonesia.

Inderasari, E., \& Agustina, T. (2017). Pembelajaran bahasa Indonesia pada mahasiswa asing dalam Program BIPA IAIN Surakarta. Jurnal Pendidikan Bahasa dan Sastra Indonesia, 6(2), 6-15.

Markhamah. 2009. Ragam Analisis Kalimat Bahasa Indonesia. Surakarta: UMS Press.

Markhamah \& Sabardila, A. 2013. Analisis Kesalahan dan Kesantunan Berbahasa. Surakarta: Universitas Muhammadiyah Press.

- 2014. Analisis Kesalahan dan Karakteristik Bentuk Pasif. Surakarta. Universitas Muhammadiyah Press.

Mutoharoh, M., Sulaeman, A., \& Goziyah, G. (2018). Interferensi Morfologi dalam Karangan Narasi Mahasiswa Thailand Semester IV Pendidikan Bahasa dan Sastra Indonesia FKIP Universitas Muhammadiyah Tangerang. Silampari Bisa: Jurnal Penelitian Pendidikan Bahasa Indonesia, Daerah, dan Asing, 1(1), 84-97.

DOI: https://doi.org/10.31540/silamparibisa.v1i1.10

Ngalim, Abdul. 2015. Sosiolinguistik: Suatu Kajian Fungional dan Analisisnya. Surakarta: PBSID FKIP UMS.

Ramaniyar, E. (2016). “Afiksasi Bahasa Melayu Dialek Sintang (Kajian Morfologi)". Jurnal Pendidikan Bahasa, 5 (2): 188-197.

Rohmadi, M., Nasucha, Y., \& Wahyudi, A. B. (2012). Morfologi: Telaah Morfem dan Kata. Surakarta: Yuma Pustaka.

Santoso, T., \& Sabardila, A. (2018).. "Analisis Kesalahan Berbahasa Pidato Mahasiswa MPB-UMS yang Memerankan Diri Menjadi Calon Kepala Daerah Kabupaten Blora”. Jurnal Penelitian Humaniora, 19 (2): 17-27.

Sudaryanto. 2015. Metode dan Aneka Teknik Analisis Babasa: Pengantar Penelitian Wabana Kebudayaan secara Linguistik. Yogyakarta: Sanata Dharma Universitas Press.

Sukmawaty. (2017). "Analisis Kesalahan Berbahasa Indonesia pada Skripsi Mahasiswa Program Studi Sistem Informasi Sekolah Tinggi Manajemen Informatika dan Komputer (STMIK) Kharisma Makassar". Jurnal Retorika, 10 (1): 56-65.

Sukoyo, J. (2011). "Interferensi Bahasa Indonesia dalam Acara Berita Berbahasa Jawa "Kuthane Dhewe" di TV Borobudur Semarang". Lingua Jurnal Bahasa dan Sastra, 7 (2): 95-103.

Yahya, M., \& Saddhono, K. (2018). Studi Kesalahan Penulisan Kalimat Dalam Karangan Pelajar Bahasa Indonesia Untuk Penutur Asing (BIPA). Dialektika: Jurnal Bahasa, Sastra, dan Pendidikan Bahasa dan Sastra Indonesia, 5(1), 1-20.

DOI: https://doi.org/10.15408/dialektika.v5i1.6295

Yahya, M., Andayani, A., \& Saddhono, K. (2018). Tendensi Kesalahan Sintaksis Bahasa Tulis Pembelajar Bahasa Indonesia bagi Penutur Asing (BIPA). Sukma: Jurnal Pendidikan, 2(1), 137-166.

DOI: https://doi.org/10.32533/02106(2018)

Verhaar, J.W.M. 2012. Asas-asas Linguistik Umum. Yogyakarta: UGM Press. 